\title{
Characterizing Biodiversity of Alpine Streams in Grand Teton National Park, Wyoming
}

\section{Authors}

Lusha M. Tronstad, Scott Hotaling, J. Joseph Giersch, Debra S. Finn, Oliver J. Wilmot, and Mark D. Anderson 


\title{
CHARACTERIZING BIODIVERSITY OF ALPINE STREAMS in Grand Teton NATiOnal PARK, WyOMing
}

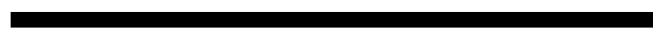 \\ $\gamma$ \\ LUSHA M. TRONSTAD $\downarrow$ UNIVERSITY OF WYOMING $\downarrow$ LARAMIE, WY \\ SCOTT HOTALING $\uparrow$ UNIVERSITY OF KENTUCKY $\uparrow$ LEXINGTON, KY \\ J. JOSEPH GIERSCH $\uparrow$ USGS GLACIER NATIONAL PARK $\uparrow$ WEST GLACIER, MT \\ DEBRA S. FINN $\uparrow$ OREGON STATE UNIVERSITY $\uparrow$ CORVALLIS, OR \\ OLIVER J. WILMOT $\uparrow$ UNIVERSITY OF WYOMING $\uparrow$ LARAMIE, WY \\ MARK D. ANDERSON $\uparrow$ UNIVERSITY OF WYOMING $\uparrow$ LARAMIE, WY
}

\begin{abstract}
$\uparrow \quad$ ABSTRACT
The highest rate of climate change is occurring in alpine areas above permanent treeline. The Teton Mountains in northwestern Wyoming are one of these ecosystem and little work has been done on alpine streams in the area. We sampled 6 streams in the Teton Mountains in 2015 at both upper and lower sites. We measured environmental variables (e.g., glacierality index, basic water quality, and temperature), aquatic invertebrate assemblages and microbial diversity. The water sources for sampled streams were glacier-fed, snowmelt and icy-seep. Aquatic invertebrate density $\left(116-11,523 \mathrm{ind} / \mathrm{m}^{2}\right)$ and biomass $\left(31-21,704 \mathrm{mg} / \mathrm{m}^{2}\right)$ varied greatly among streams. Snowmelt streams had the highest biomass of invertebrates, but the density and richness did not differ among stream types. Micrbial diversity in groundwater-fed springs harbored higher diversity than glacier-fed streams. The discovery of an icy-seep stream type lead us to sample rock glacier in the Teton Mountains during 2016. We hope to continue to sample alpine streams in the Teton Mountains to understand how climate change will alter streams of different types.
\end{abstract}

\section{$\uparrow \quad$ INTRODUCTION}

The highest rates of climate change are occurring above the permanent treeline in alpine and arctic ecosystems (Bradley et al. 2006). In the Rocky Mountains, warming is proceeding at two to three times the rate of the global average (Hansen et al. 2005, Pederson et al. 2010), resulting in extensive loss of glaciers and snowpack at higher-elevations (Hall and Fagre 2003). Environmental changes to mountain streams expected with climate change include a general shift upward of biological communities (Finn et al. 2010, Sheldon 2012, Giersch et al. 2015, Hotaling et al. in press), ultimately taking a significant toll on freshwater biodiversity. This loss of biodiversity will especially be seen in high-gradient alpine streams, as the diverse assemblage of species that can only live in a narrow temperature range are especially vulnerable to warming and snow loss (Brown et al. 2007, Hotaling et al. in press). Streams with physically steep gradients are accompanied by similarly steep gradients of species turnover, a pattern well-documented for aquatic macroinvertebrates (Allan 1975, Finn and Poff 2005, Sheldon and Warren 2009, Finn et al. 2013). Although alpine streams undergo extended periods of cold temperatures throughout the year, increased solar radiation during the late summer and the lack of canopy cover results in rapid warming of the water downstream of glaciers and snowfields, further isolating coldwater dependent species to short sections near the source (Ward 1994). Additionally, these streams tend to be geographically isolated from one another by either distance among mountain ranges or by dispersal barriers caused by extreme topography (Finn et al. 2006, Clarke et al. 2008), limiting gene flow. Along with increasing temperatures, additional effects may include increasing stream conductivity and water temperature. Macroinvertebrate diversity at the mountain range scale is predicted to decrease due to summit traps (i.e., highest-altitude species and communities having nowhere higher to disperse as the environmental gradient shifts upward), as well as loss of specific types of aquatic habitat, particularly the unique 
conditions associated with meltwater from oncepermanent sources like glaciers, snowfields, or subterranean ice (Brown et al. 2007, Milner et al. 2009, Jacobsen et al. 2012, Finn et al. 2013, 2014, Hotaling et al. in press).

A number of recent studies, primarily in European alpine streams, have attempted to predict the degree to which regional aquatic macroinvertebrate biodiversity will be impacted by climate change, especially following decreasing or complete loss of glacial meltwater hydrology (Hotaling et al. in press). These studies have used space-for-time observational approaches (i.e., monitoring stream reaches with varying current degrees of meltwater influence; Brown et al. 2007, Finn et al. 2013) and/or modeling (Bálint et al. 2011, Khamis et al. 2014). These studies came to the general conclusion that loss of alpine meltwater sources will result in decreased regional biodiversity and that alpine stream fauna will be increasingly dominated by the species, communities, and genetics of streams fed primarily by groundwater (which are expected to remain after permanent meltwater sources are gone). In other words, the decreasing environmental heterogeneity that will accompany disappearing meltwater sources will likely result in the loss of biodiversity at the mountain-range scale.

Closer to home, the alpine invertebrates in streams of the Rocky Mountains are receiving increased attention. Previously unknown, endemic species have been described (e.g., Lednia tetonica, Teton Range; Baumann and Call 2012), uphill range contractions have been documented (e.g., Zapada glacier in Glacier National Park; Giersch et al. 2015), putatively undescribed alpine species are being discovered (Finn and Poff 2008, Giersch et al. 2016), and the ecology of previously described alpineendemic species is being evaluated (e.g., Finn and Poff 2005, 2008, Muhlfeld et al. 2011, Giersch et al. 2015, 2016); however, no work has been done in the alpine streams of Grand Teton National Park (GRTE). Studies investigating population genetic structuring of Rocky Mountain alpine-endemic species have revealed strong structure across relatively short geographic distances (Finn et al. 2006, Finn and Adler 2006, Giersch et al. 2015), suggesting that local populations are evolving in isolation, a pattern expected to be exacerbated as climate change proceeds and habitat is further reduced. The potential reduction of biodiversity in response to anthropogenic climate change should be considered in terms of both morphological and genetic diversity loss. For instance, Bálint et al. (2011) showed that under future warming scenarios, the net loss of cryptic genetic diversity will greatly exceed loss of species diversity. Aside from obvious conservation implications associated with a reduction in genetic diversity among extant populations, this loss of genetic diversity may also hinder the adaptive potential of populations in response to rapidly changing environments (Hoffman and Sgrö 2011).

Rocky Mountain and European studies both concluded that continued climate change will result in the loss of permanent meltwater sources (e.g., glaciers and snowfields) and upstream shifts of environmental gradients. These changes are predicted to lead to the loss of endemic species in the highest reaches of alpine streams and to decrease regional biodiversity of stream biota. Interestingly, very little is known of the alpine stream assemblages of GRTE. GRTE has unique characteristics relevant to its alpine streams. First, GRTE is a young range composed of granite and sedimentary bedrocks. Therefore, spring-fed streams may be rare, especially at higher altitudes in the granite areas (L. Tronstad, personal observation). This potential lack of stable, spring-fed streams suggest that a loss of permanent meltwater sources could result in alpine streams shifting from permanent to intermittent. Such a shift from permanent to intermittent streamflow would have a strong impact on invertebrate communities, as many aquatic insects in alpine streams lack the life history characteristics necessary to survive drying (Finn and Poff 2005, Poff et al. 2010). A second important characteristic of GRTE is its geographic setting in the Middle Rockies which are understudied. This region is important biogeographically given hypotheses of the Rocky Mountain spine as a narrow dispersal corridor for alpine taxa connected all the way from Beringia (Siberia/Alaska) to the Southern Rockies of Colorado (Finn and Adler 2006).

Here, we report on preliminary results of our efforts to sample aquatic biodiversity of the highestaltitude streams of GRTE in 2015. Our proposed objectives were three-fold. 1.) Most fundamentally, we aimed to characterize the alpine communities of aquatic invertebrates occupying the Teton Range of GRTE. Compared to other national parks in the Rocky Mountains containing a high density of alpine streams (e.g., Rocky Mountain and Glacier National Parks), very little is known of alpine stream invertebrates in GRTE. 2.) We also implemented a sample stategy specifically designed to characterize variation in aquatic invertebrate assemblages and environmental variables between glacier-fed and non-glacier-fed alpine streams in GRTE. This objective included both macroinvertebrate community sampling and measuring environmental variables known to vary 
between glacier-fed and non-glacier-fed alpine streams. With these data, we will be able to understand the degree to which glacier meltwater drives a unique community structure and contributes to regional biodiversity. Results will provide insight into how we might expect biodiversity patterns to shift as permanent meltwater sources disappear. 3.) We proposed to assess basic patterns of intraspecific genetic diversity among drainage basins in resident GRTE alpine-stream invertebrates. Intraspecific genetic diversity comprises an important component of regional biodiversity and the results of this objective will provide insight into whether environmental drivers affect species diversity and population-genetic diversity in alpine streams (as has been observed elsewhere) as well as the degree of connectivity linking populations of these alpineendemic species both within GRTE, and between Glacier National Park and other portions of the Rocky Mountain Range.

Beyond these originally proposed objectives, we also took the opportunity to collect and analyze microbial samples from the same GRTE study sites. The goal of this fourth objective was to assess the degree to which biodiversity at this additional taxonomic scale varied across the same habitats discussed in the context of macroinvertebrate and genetic diversity above.

\section{$\downarrow \quad$ METHODS}

\section{Study sites}

In August 2015, we sampled three pairs of alpine stream reaches, initially paired according to hypothesized dominant hydrological source of streamflow. Pairs chosen prior to 2015 fieldwork included one representative "icemelt" stream from either surface glacier or subterranean ice and one stream of predominantly seasonal snowmelt source, with no surface glacier present in the drainage basin. In each of the six streams representing the three pairs, we established one upstream and one downstream sample site, such that the total number of sites sampled was $\mathrm{N}=12$ (Figure 1).

Included in the three pairs of streams are each of the sites for which we had previous records (published or unpublished) of either L. tetonica or $Z$. glacier. Generally, site pairs straddle a drainage divide, such that geology is as similar as possible within pairs. Pairings were as follows:

- Petersen Glacier stream (Figure 2A) and North Fork Teton Creek (Figure 2B). The Petersen
Glacier stream drains to the east and feeds Mica Lake, and North Fork Teton Creek is fed primarily by snowmelt and drains to the west.

- Middle Teton glacier stream (Figure 2C) and South Fork Cascade Creek (Figure 2D). This pairing covered the east and west sides of the Middle Teton and included a putatively snowmelt-fed stream (S. Cascade Creek) where L. tetonica and Z. glacier had previously been documented in small tributaries to the drainage.

- South Fork Teton Creek (Alaska Basin; Figure 2E) and Wind Cave stream (Darby Creek drainage) (photos Figure 2F). While this pairing does not include a true glacial source, the stream originating from Wind Cave is fed by permanent, subterranean ice and is the only published locality for L. tetonica. S. Fork Teton Creek is a 'classic' snowmelt alpine stream that has yielded samples of either Z. glacier or a potentially undescribed Zapada species (see Giersch et al. 2016).

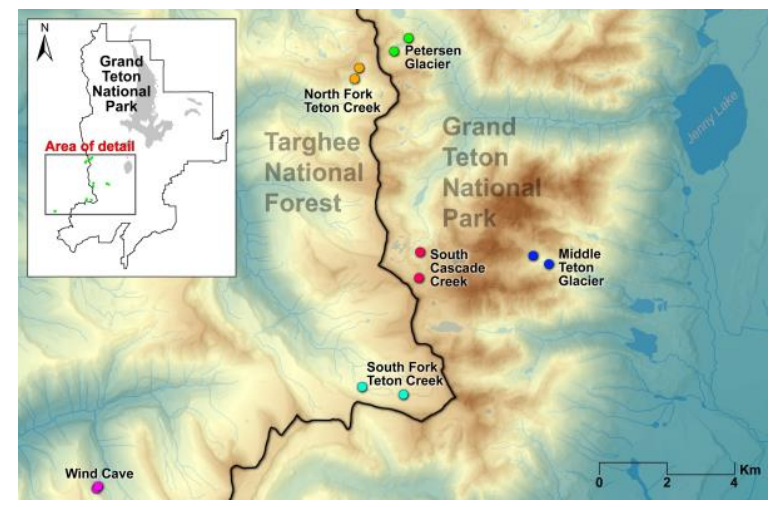

Figure 1. Locations of 12 sample sites, including upper and lower reaches on each of six streams.

\section{Macroinvertebrate sampling}

We collected quantitative benthic invertebrate data from each sample site using a Surber sampler (area $0.09 \mathrm{~m}^{2}, 243 \mu \mathrm{m}$ mesh size). Number of replicate Surber samples ranged from 5 to 10 at each site and depended on stream size and density of macroinvertebrates. Invertebrates were sorted from the debris, and identified, counted and measured under a dissecting microscope using Merritt et al. (2008) and Thorp and Covich (2010). We measured the length of the first 20 individuals of each taxon and calculated biomass using length-mass regresions (Benke et al. 1999). The data were standardized as the number of individuals and biomass per $\mathrm{m}^{2}$. Samples were elutriated in the field to reduce the amount of inorganic substrate and stored in Whirl-Pak bags with 90\% 
ethanol. In the laboratory, invertebrate samples were divided into large $(>2 \mathrm{~mm})$ and small fractions (between $250 \mu \mathrm{m}$ and $2 \mathrm{~mm}$ ), and the small fraction was subsampled using a record player subsampler when necessary (Waters 1969). Specimens are currently preserved in the lab (L. Tronstad) in $90 \%$ ethanol in preparation for genetic data collection.
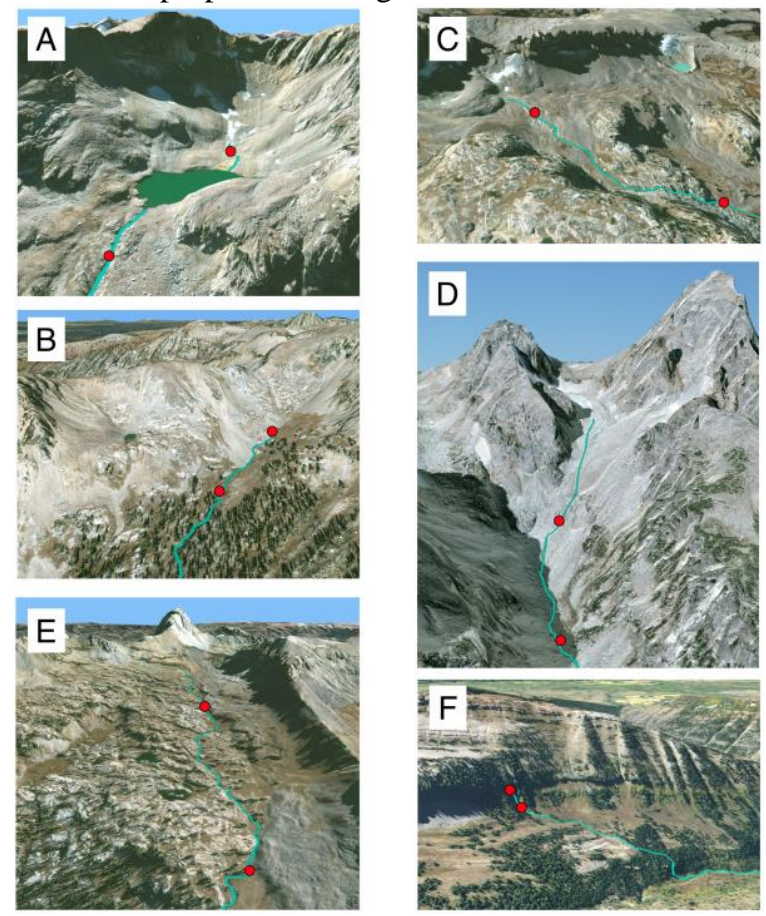

Figure 2. Images of the six 2016 sample basins and locations of $\mathrm{N}=12$ stream sample sites (red dots) from satellite imagery draped over elevation data in ArcGIS. A) Petersen Glacier stream (with Mica Lake); B) N. Fork Teton Creek; C) S Fork Cascade Creek (Schoolroom Glacier in upper right of panel); D) Middle Teton stream; E) S Fork Teton Creek in Alaska Basin; F) Wind Cave stream in Darby Canyon.

\section{Environmental data collection}

We deployed temperature dataloggers (HOBO) at each of the 12 sample sites in August 2015 and allowed them to run for approximately one year, returning to collect them in August 2016. Data were recorded at one-hour intervals for the full year. We also measured a suite of environmental variables commonly used to characterize the degree of glacier meltwater influence (Ilg and Castella 2006, Finn et al. 2013). These included four key variables: water temperature patterns (data from loggers described above), electrical conductivity (measured with a YSI Professional Plus Multiprobe), physical habitat stability (with a modified version of the Pfankuch Index for streambed stability, which has been demonstrated to work well in mountain streams, Peckarsky et al. 2014), and suspended sediments (filtered from water samples in the field, then dried and weighed in the lab). We also made spot estimates of stream discharge $\left(\mathrm{m}^{3} / \mathrm{sec}\right)$ for each sample site during mid-day hours (ca. 10:00-16:00) on each visit, using a Global Water Flow Probe. We used a YSI Sonde to record dissolved oxygen concentration, oxidationreduction potential, water temperature and $\mathrm{pH}$.

\section{Microbial data collection and analyses}

In the field, we collected microbial samples for the upper sample sites on each of the six focal streams (Figure 1). At each site, we sampled streamwater, biofilm from benthic substrate, and when applicable, source snow or ice. All samples were filtered in the field using $0.2 \mu \mathrm{m}$ sterile filters. Ice was melted before filtering. Biofilm samples were collected by scrubbing rocks with sterile tools, rinsing them with sterile water, and filtering the rinse water. For most localities, three replicates were collected and these were subsampled/combined during DNA extraction.

DNA was extracted and the V4 region of the 16S rRNA was amplified using a modified Direct-toPCR approach (Flores 2012). Unique combinations of Illumina barcodes were incorporated into each sample during PCR. Amplicons were sequenced using Illumina MiSeq sequencing with 250 bp paired-end chemistry. Forward and reverse reads were merged using FLASH (Magoc 2011). Reads were then quality filtered using FastX-Toolkit (Hannon 2010). 83\% of a read had to have a quality score $(\mathrm{Q})$ of 24 or higher to be included in downstream analyses. QIIME (Caporaso et al. 2010) was used for all additional data filtering (e.g., removal of putative chimeras) and analyses. Operational Taxonomic Units (OTUs) were assigned using $\geq 97 \%$ similarity. Given the challenges of removing all microbial contaminants during the molecular component of the process, we elected to sequence a PCR negative. After OTU calling, we removed dominant negative OTUs from all samples. Two of these were members of the human-associated genera Propionibacterium and Streptococcus. After filtering, all samples $(\mathrm{N}=36)$ were rarified to the lowest common number of sequence reads: 37,469 . As an initial step in analyzing the microbial data, we compared Shannon diversity across samples and microhabitats, compared alpha diversity between samples, and quantified the make-up of individual microbial communities at the Family level. We also made initial comparisons to a data set with nearly identical experimental design, collected in Glacier National Park, MT in 2015. 


\section{Data analysis}

Our paired sample design, which included one currently glaciated (or containing subterranean ice in the case of the Wind Cave stream) and one ice-free basin on either side of a drainage divide, allows a robust statistical approach to assess whether significant differences in environmental and/or biological characteristics exist between directly icefed streams and streams fed by other alpine sources. We used a multivariate framework (PCA, within the PC-ORD software, McCune and Mefford 2006) to characterize each stream according to the suite of variables indicating degree of meltwater influence. We are in the process of characterizing biodiversity at both the community level (macoinvertebrates and microbes) and the intraspecific population-genetic level for the rare/endemic macroinvertebrate species. Population-genetic patterns of biodiversity will be determined according to haplotype distribution at the mitochondrial COI locus within and among populations, data generated according to standard methods (e.g., Finn et al. 2013, Giersch et al. 2015). Spatial biodiversity patterns at both community and population levels are being estimated as alpha (per sample site), gamma (whole region, i.e., all sites combined), and beta (variation from one local site to the next) diversity with common statistics for partitioning regional-scale biodiversity (e.g., Finn et al. 2011, 2013, Kubo et al. 2013). By applying the same biodiversity statistics at both community and population-genetic levels of organization, we will be able to assess the degree to which environmental differences in Teton high-alpine streams influence species and genetic diversity in a parallel manner. We will also be able to compare the genetic results from the commonly measured COI sequence data to other alpine species (e.g., Lednia tumana in Glacier National Park) and around the world.

\section{$\downarrow \quad$ PRELIMINARY RESUlTS}

\section{Environmental differences among streams}

We preliminarily classified streams according to four variables associated with degree of glacier meltwater influence: streambed and channel stability, conductivity, suspended sediments in the water column, and spot daytime water temperature. (Note that while we retrieved all temperature dataloggers in August 2016 we have not completed data analysis.) The Pfankuch Index (streambed stability; lower values $=$ higher stability) ranged across the upper sites of our six streams from 15 (N Fork Teton Creek snowmelt stream) to 42 (at both the Petersen Glacier and Middle Teton Glacier streams).
Higher specific conductivity is expected in streams fed by groundwater and lower specific conductivity is expected in streams with little groundwater influence. For the six study sites, specific conductivity ranged from $3.7 \mu \mathrm{S} / \mathrm{cm}$ (Petersen Glacier stream) to 176.8 $\mu \mathrm{S} / \mathrm{cm}$ (Wind Cave stream). Suspended sediments in the water column ranged from undetectable in the Wind Cave stream to $34.5 \mathrm{mg} / \mathrm{L}$ in the Petersen Glacier stream. Spot summer daytime water temperature ranged from $0.3^{\circ} \mathrm{C}$ in the Petersen Glacier stream to $11.8^{\circ} \mathrm{C}$ in $\mathrm{S}$. Fork Teton Creek (Alaska Basin).

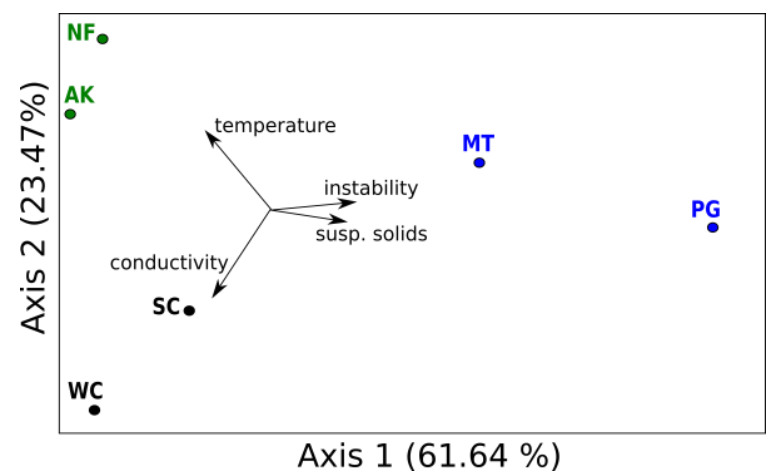

Figure 3. Results of principal components analysis (PCA) showing the environmental heterogeneity among the uppermost reaches of the six alpine streams sampled in 2015. Sites in blue (MT = Middle Teton glacier stream, PG = Petersen Glacier stream) group together and represent streams fed predominantly by surface runoff from glaciers. Sites in green $(\mathrm{NF}=$ North Fork Teton Creek, $\mathrm{AK}=$ South Fork Teton Creek in Alaska Basin) group together and are likely fed predominantly by seasonal snowmelt runoff. The two sites marked in black include the Wind Cave stream (WC), fed by subterranean ice, and the S Cascade stream (SC) that we originally thought was a seasonal snowmelt-dominated stream but the environmental characteristics suggest the possibility of an alternative, subterranean ice-like hydrological source.

The PCA combining these four key variables (Figure 3) suggests three primary stream types. Sites in blue are fed by surficial runoff from glaciers and are characterized by high streambed instability, high suspended solids in the water column, and low conductivity. Sites in green are fed by seasonal snowmelt and are characterized by higher water temperatures, higher streambed stability, and low suspended solids. Sites in black are seemingly grouped according to low water temperature, high conductivity (indicating groundwater influence), high streambed stability, and low suspended sediments (high water clarity). We expected the Wind Cave stream in this unique group; however, we expected the $\mathrm{S}$ Cascade Creek site to group with the sites marked in green 
representing seasonal snowmelt-fed streams. Rather, it appears likely that this stream is fed primarily by subterranean ice, perhaps from a rock glacier. Analysis of the long-term temperature data will help resolve this issue, as well as recent efforts to identify rock glaciers in the Teton Range (see Fegel et al. 2016) but the implication is that rock glaciers, which are common in the high Tetons, could be a vital hydrological source for a unique alpine stream type in GRTE (Figure 4).

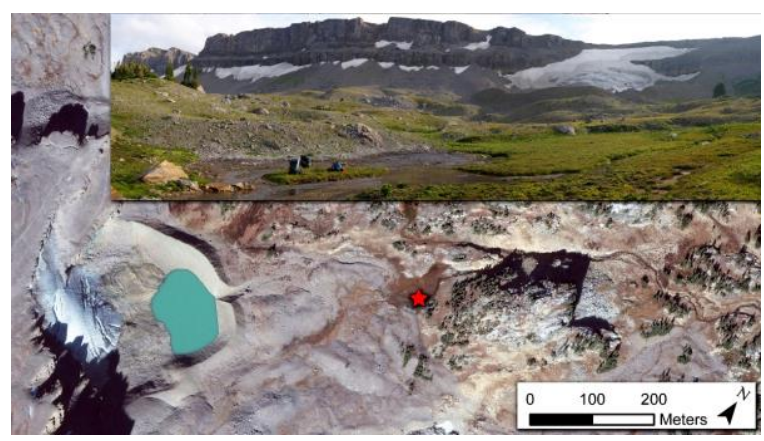

Figure 4. A photo and satellite image of what we have termed an 'icy seep' stream type (black dots in PCA, Figure 3) in GRTE below Schoolroom Glacier. The red star is a location where Lednia tetonica was collected in 2015 (but was not one of the focal six sample streams for the current project).

\section{Macroinvertebrate diversity}

We collected macroinvertebrate community data from 12 sites in the GRTE (Figure 1). L. tetonica was present in four of the six basins, including the location of it's original description, Wind Cave (Baumann and Call 2012), an undescribed tributary to S. Fork Cascade Creek near Schoolroom Glacier (Figure 4), S. Fork Teton Creek in Alaska Basin, and the lower sample site on the Petersen Glacier stream. We collected Zapada species from all six basins (S. Fork Cascade Creek, S. Fork Teton Creek in the Alaska Basin, Wind Cave, a Teton Meadows tributary to the Middle Teton Glacier stream, the lower sample site on the Petersen Glacier stream, and N. Fork Teton Creek). We have tentatively identified the specimens from the Tetons as $Z$. glacier, but more thorough genetic analysis is needed. If the stoneflies in the Teton Range are Z. glacier, we would show that this species is more widely distributed than previously thought.

We have analyzed invertebrate samples from 8 sites in the Tetons (Table 1). Invertebrates had the highest densities in the stream below Middle Teton Glacier and the upper site of S. Fork Cascade Creek and biomass was highest in the S. Fork Teton Creek in Alaska Basin. S. Fork Teton Creek in the Alaska Basin also had the highest diversity of invertebrates. The density (ANOVA; $P=0.84)$ and richness $(P=0.14)$ of invertebrates did not vary by stream water source (i.e., glacier, snowmelt or ice), but the biomass of invertebrates varied by water source $(P=0.003)$. Snowmelt sites had higher biomass than the other types of streams and snowmelt sites had higher richness than streams below glaciers.

Table 1. Density, biomass and richness (R) of invertebrates in alpine streams in the Teton Mountains.

\begin{tabular}{|l|l|l|l|l|}
\hline Stream & Site & $\begin{array}{l}\text { Density } \\
\left(\mathbf{i n d} / \mathbf{m}^{\mathbf{2}}\right)\end{array}$ & $\begin{array}{l}\text { Biomass } \\
\left(\mathbf{m g} / \mathbf{m}^{\mathbf{2}}\right)\end{array}$ & $\mathbf{R}$ \\
\hline \multirow{2}{*}{$\begin{array}{l}\text { Petersen } \\
\text { Glacier }\end{array}$} & Lower & 294 & 658 & 13 \\
\cline { 2 - 5 } $\begin{array}{l}\text { Middle } \\
\text { Teton }\end{array}$ & Upper & 116 & 31 & 6 \\
\hline \multirow{2}{*}{$\begin{array}{l}\text { South } \\
\text { Cascade }\end{array}$} & Upper & 11,523 & 2507 & 7 \\
\hline \multirow{2}{*}{$\begin{array}{l}\text { Teton Creek } \\
\text { AK Basin }\end{array}$} & Lower & 11,694 & 753 & 8 \\
\cline { 2 - 5 } & Upper & 1545 & 8050 & 17 \\
\cline { 2 - 5 } & Upper & 4165 & 21,704 & 27 \\
\hline
\end{tabular}

\section{Microbial diversity}

After quality filtering and removal of putative contaminants and singleton OTUs, we identifed 2.87M reads for 36 libraries ( $\mathrm{min} .=37,798$; max. $=314,040)$. Streamwater was consistently the most diverse microhabitat sampled, with source ice or snow intermediate, and biofilms having the lowest diversity (Figure 5). Source appears to heavily influence microbial community diversity with groundwater-fed springs harboring greater diversity than glacier-fed streams. Interestingly, ice-fed biofilms were some of the least diverse biofilms sampled, yet associated streamwater was among the highest (Figure 5). When viewed in PCoA space, biofilm and streamwater samples are widespread, meaning there is greater variation among their assemblages. Ice (from the surface of both glaciers and snowfields) samples formed a much tighter grouping (Figure 6). Proteobacteria were significant portions of almost all sampled communities. Bacteriodetes was most abundant in ice and Cyanobacteria dominated many biofilm communities. Streamwater was consistently the most diverse microhabitat in terms of total phyla observed (Figure 7). In the Swiss Alps, Wilhelm et al. (2013) focused on microbial biodiversity of glacier-fed streams only. Our PCoA results are similar with ice forming a tight, distinct cluster and biofilms/streamwater having broader profiles. However, from a total diversity perspective, Wilhelm et al. (2013) identified an increase from ice to streamwater to biofilms, whereas in our study, we see much lower diversity in glacier-fed biofilms but similar values for ice and streamwater. 


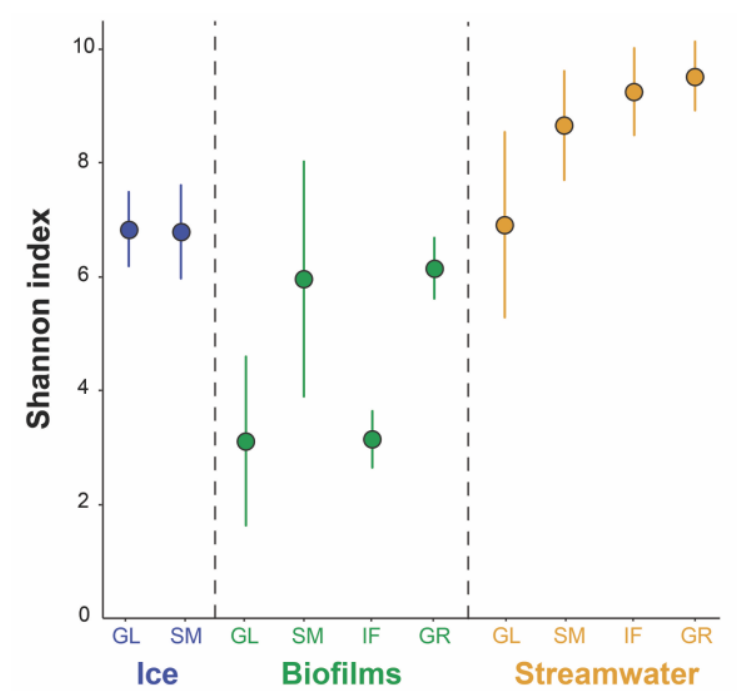

Figure 5. Shannon's diversity index for each microhabitat (ice, biofilm, streamwater) and source. Higher values indicate greater taxonomic diversity. Dark lines represent standard error. Source abbreviations: Glacial fed = GL, Icefed streams $=$ IF, Snowmelt fed $=$ SM, Groundwater-fed streams $=$ GR. This figure includes complementary data from Glacier National Park, Montana.

\section{$\uparrow \quad$ CONCLUSIONS}

Our results clearly show that three key "stream types" exist in the Teton Range: snowmelt, glacier-fed, and an "icy seep". The unexpected third type is likely fed by the melting of subterranean ice and acts as an intermediate between snowmelt and glacier-fed streams. The existence of this third stream type represents an area of strong interest both in the Teton Range and alpine stream biology (Hotaling et al. in press) as the subterranean ice type could be more resistant to the effects of climate change (Hotaling et al. in press). Though the ice source of these habitats appears to result in temperature profiles similar to those of glacial streams, the limited sediment load, low turbulence, and stable flows may result in different community composition altogether. In GRTE, this is especially important given the presence of rare, endemic species in these icy seeps.

Our efforts have also expanded the known distributions of two rare stoneflies - L. tumana and $Z$. glacier - imperiled by climate-induced loss of glaciers and snowfields. (Giersch et al. 2016). L. tumana was previously only known from a single site just west of GRTE, Wind Cave, and our surveys identified three additional streams, two of which are within GRTE. For Z. glacier, preliminary results from COI barcoding of Zapada nymphs has revealed an additional population from the inlet to Delta Lake, and further sampling will likely yield more locations of this species as well as shed additional light on the possibility of cryptic Zapada species present within GRTE and across the American West. Of particular interest is a monophyletic clade, termed 'WY-NM' by Giersch et al. (2016) that appears to be an underscribed Zapada species ranging from GRTE to northern New Mexico.

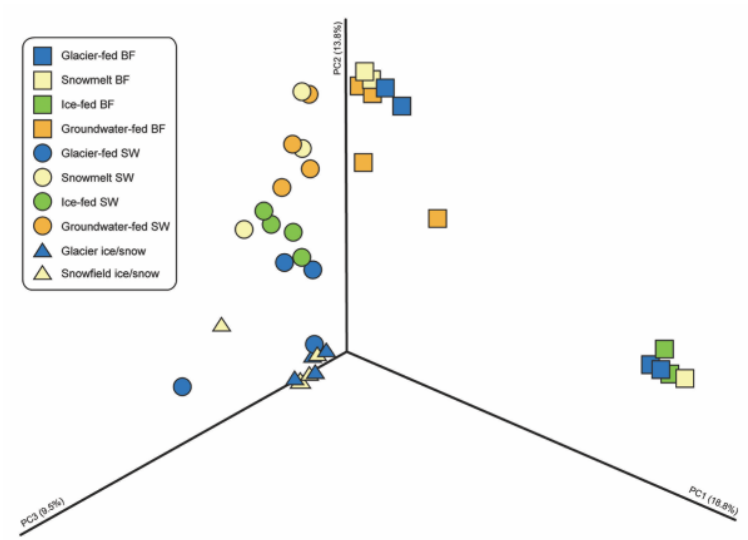

Figure 6. 3D Principal coordinates analysis ( $\mathrm{PCoA})$ of the 36 samples included in this study. Dissimilarity values are Bray-Curtis. Samples are grouped by source (color) and microhabitat (shape). Microhabitat abbreviations: Springwater $=\mathrm{SW}$ and Biofilm $=\mathrm{BF}$. This figure includes complementary data from Glacier National Park, Montana.

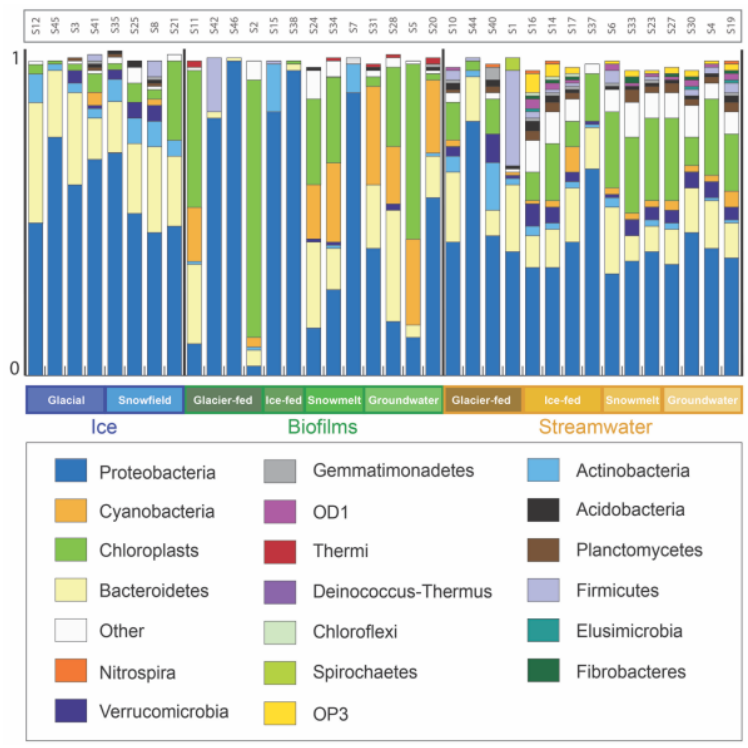

Figure 7. Dominant phyla (those found at greater than $1 \%$ frequency) for each sample grouped by source (colored text) and microhabitat (colored boxes). Reported values for Cyanobacteria are with Chloroplasts separated out. All samples do not equal one as many trace phyla were not included. This figure includes complementary data from Glacier National Park, Montana. 
The streams we sampled in the Tetons varied from extremely low to high densities. The density of invertebrates collected in a stream below a glacier in the Austrian Alps (2798 ind $/ \mathrm{m}^{2}$; Füreder et al. 2001) was lower than Middle Teton and higher than Petersen Glacier. Additionally, they estimated that the density of invertebrates in a nearby spring-fed stream was higher $\left(5357 \mathrm{ind} / \mathrm{m}^{2}\right)$. We measured much variation in our samples, including between glacier-fed sites. Further analysis of the invertebrate assemblages with environmental data will further explain the variation we observed in our data.

For microbial taxa, it is clear that a diverse, active community of microscopic organisms are at work in alpine streams of the Teton Range. Initial comparisons to Glacier National Park reveal little effect of mountain range on microbial diversity. Rather, microhabitat (i.e., ice/snow, streamwater or biofilm) appears to be a significant influence of community composition, a pattern also observed by Wilhelm et al. (2013).

\section{$\uparrow \quad$ FUTURE WORK}

Given our identification of a potentially novel alpine stream type from our 2015 efforts, a major goal of the 2016 field season was to sample additional sites with a specific focus on rock glaciers. We hope to use these data to select alpine stream monitoring sites in the Teton Range. Alpine streams are predicted to be strongly impacted by climate change and we are not aware of any other efforts monitoring stream assemblages in the area. For both the 2015 and 2016 samples, an ongoing goal is to generate COI sequence data for L. tetonica, Z. glacier, and any other alpine-obligate taxa that emerge from our macroinvertebrate analyses. The goals of this genetic data collection are two-fold: 1) to compare population-genetic diversity across (and within) study sites, and 2) to aid in addressing our overarching hypotheses regarding how biodiversity varies with glacier influence across taxonomic scales.

Our primary future goal is to compare results across levels of taxomic resolution (i.e., micro- and macroscopic species and macroscopic genetic diversity) to better understand the influence of alpine glaciers and other habitat characteristics on biodiversity. While individual examples of glaciers acting as important drivers of biodiversity have been made elsewhere, incorporating these three data sets for the same mountain range and streams will provide powerful evidence for or against this hypothesis. Moreover, efforts to collect complementary data are ongoing for Glacier National Park, and we intend to continue broadening the geographic scope of this project (and comparisons) to other mountain ranges in North America (e.g., North Cascades, Olympic, Sierra Nevada).

Lastly, given the conservation discussion surrounding $Z$. glacier, and specifically, the possibility of distinct $Z$. glacier species inhabiting each mountain range where it occurs, a project incorporating genomic data to robustly assess $Z$. glacier species boundaries is ongoing.

\section{$\uparrow \quad$ ACKNOWLEDGEMENTS}

We thank the UW-NPS Research Station and Teton Conservation District for financial support.

\section{$\uparrow \quad$ Literature Cited}

Allan, J.D. 1975. The distributional ecology and diversity of benthic insects in Cement Creek, Colorado. Ecology 56:1040-1053.

Bálint, M. et al. 2011. Cryptic biodiversity loss linked to global climate change. Nature Climate Change 1:313-318.

Baumann, R.W., and R.G. Call. 2012. Lednia tetonica, a new species of stonefly from Wyoming (Plecoptera:Nemouridae). Illiesia 8:104-110.

Benke, A.C., A.D. Huryn, L.A. Smock, and J.B. Wallace. 1999. Length-mass relationships for freshwater macroinvertebrates in North America with particular reference to the southeastern United States. Journal of the North American Benthological Society 18:308-343.

Bradley, R.S., M. Vuille, H.F. Diaz, and W. Vergara. 2006. Threats to water supplies in the tropical Andes. Science 312:1755-1756.

Brown, L.E., D.M. Hannah, and A.M. Milner. 2007. Vulnerability of alpine stream biodiversity to shrinking glaciers and snowpacks. Global Change Biology 13:958-966.

Clarke, A., R. Mac Nally, N. Bond, and P.S. Lake. 2008. Macroinvertebrate diversity in headwater streams: A review. Freshwater Biology 53:1707-1721.

Fegel, T.S., J.S. Baron, A.G. Fountain, G.F. Johnson, and E.K. Hall. 2016. The differing biogeochemical and microbial signatures of glaciers and rock glaciers. Journal of Geophysical Research-Biogeosciences 121:919-932.

Finn, D.S., and P.H. Adler. 2006. Population genetic structure of a rare high-elevation black fly, Metacnephia coloradensis, occupying 
Colorado lake outlet streams. Freshwater Biology 51:2240-2251.

Finn, D.S., N. Bonada, C. Murria, and J.M. Hughes. 2011. Small but mighty:headwaters are vital to stream network biodiversity at two levels of organization. Journal of the North American Benthological Society 30:963-980.

Finn, D.S., K. Khamis, and A.M. Milner. 2013a. Loss of small glaciers will diminish beta diversity in Pyrenean streams at two levels of biological organization. Global Ecology and Biogeography 22:40-51.

Finn, D.S., and N.L. Poff. 2005. Variability and convergence in benthic communities along the longitudinal gradients of four physically similar Rocky Mountain streams. Freshwater Biology 50:243-261.

Finn, D.S., and N.L. Poff. 2008. Emergence and flight activity of alpine stream insects in two years with contrasting winter snowpack. Arctic, Antarctic, and Alpine Research 40:638-646.

Finn, D.S., K. Räsänen, and C.T. Robinson. 2010. Physical and biological changes to a lengthening stream gradient following a decade of rapid glacial recession. Global Change Biology 16:3314-3326.

Finn, D.S., D.M. Theobald, W.C. Black, and N.L. Poff. 2006. Spatial population genetic structure and limited dispersal in a Rocky Mountain alpine stream insect. Mol Ecol 15:3553-3566.

Finn, D.S., C. Zamora-Muñoz, C. Múrria, M. SáinzBariáin, and J. Alba-Tercedor. 2013b. Evidence from recently deglaciated mountain ranges that Baetis alpinus (Ephemeroptera) could lose significant genetic diversity as alpine glaciers disappear. Freshwater Science 33:207-216.

Füreder, L. C. Schütz, M. Wallinger and R. Burger. 2001. Physico-chemistry and aquatic insects of a glacier-fed and a spring-fed alpine stream. Freshwater Biology 46:1673-1690.

Giersch, J.J., S. Hotaling, R.P. Kovach, L.A. Jones, and C.C. Muhlfeld. 2016. Climate-induced glacier and snow loss imperils alpine stream insects. Global Change Biology.

Giersch, J.J. et al. 2015. Climate-induced range contraction of a rare alpine aquatic invertebrate. Freshwater Science 34:53-65.

Hall, M.H.P., and D.B. Fagre. 2003. Modeled climateinduced glacier change in Glacier National Park, 1850-2100. Bioscience 53:131-140.

Hansen, J. et al. 2005. Earth's energy imbalance: Confirmation and implications. Science 308:1431-1435.
Hoffmann, A.A., and C.M. Sgrö. 2011. Climate change and evolutionary adaptation. Nature 470:479-485.

Hotaling, S., D.S. Finn, J.J. Giersch, D.W. Weisrock, and D. Jacobsen. in press. Climate change and alpine stream biology: Progress, challenges, and opportunites for the future. Biol. Rev.

Ilg, C., and E. Castella. 2006. Patterns of macroinvertebrate traits along three glacial stream continuums. Freshwater Biology 51:840-853.

Jacobsen, D., A.M. Milner, L.E. Brown, and O. Dangles. 2012. Biodiversity under threat in glacier-fed river systems. Nature Climate Change 2:361-364.

Khamis, K., D.M. Hannah, L.E. Brown, R. Tiberti, and A.M. Milner. 2014. The use of invertebrates as indicators of environmental change in alpine rivers and lakes. Science of The Total Environment 493:1242-1254.

Kubo, J.S. et al. 2013. Aquatic insect assemblages associated with subalpine stream segment types in relict glaciated headwaters. Insect Conservation and Diversity 6:422-434.

McCune, B., and M. Mefford. 2006. C-ORD. Multivariate analysis of ecological data. Version 5.

Merritt, R.W., K.W. Cummins and M.B. Berg (ed.). 2008. An Introduction to the Aquatic Insects of North America. $4^{\text {th }}$ edition. Kendall Hunt Publishing Company, Dubuque, Iowa.

Milner, A.M., L.E. Brown, and D.M. Hannah. 2009. Hydroecological response of river systems to shrinking glaciers. Hydrological Processes 23:62-77.

Muhlfeld, C.C. et al. 2011. Climate change links fate of glaciers and an endemic alpine invertebrate. Climatic Change 106:337-345.

Peckarsky, B.L. et al. 2014. Characterizing disturbance regimes of mountain streams. Freshwater Science 33:716-730.

Pederson, G.T., L.J. Graumlich, D.B. Fagre, T. Kipfer, and C.C. Muhlfeld. 2010. A century of climate and ecosystem change in Western Montana: What do temperature trends portend? Climatic Change 98:133-154.

Poff, N.L., M.I. Pyne, B.P. Bledsoe, C.C. Cuhaciyan, and D.M. Carlisle. 2010. Developing linkages between species traits and multiscaled environmental variation to explore vulnerability of stream benthic communities to climate change. Journal of the North American Benthological Society 29:1441-1458. 
Sheldon, A.L. 2012. Possible climate-induced shift of stoneflies in a southern Appalachian catchment. Freshwater Science 31:765-774.

Sheldon, A.L., and M.L. Warren Jr. 2009. Filters and templates: Stonefly (Plecoptera) richness in Ouachita Mountains streams, U.S.A. Freshwater Biology 54:943-956.

Thorp, J. H. and A.P. Covich (ed.). 2010. Ecology and Classification of North American Freshwater Invertebrates. $3^{\text {rd }}$ edition. Academic Press, London, United Kingdom.
Tronstad, L.M., S. Hotaling, and J.C. Bish. 2016. Longitudinal changes in stream invertebrate assemblages of Grand Teton National Park, Wyoming. Insect Conservation and Diversity 9:320-331.

Ward, J.V. 1994. Ecology of alpine streams. Freshwater Biology 32:277-294.

Waters, T.F. 1969. Subsampler for dividing large samples of stream invertebrate drift. Limnology and Oceanograph 14:813-815.

Wilhelm, L., G.A. Singer, C. Fasching, T.J. Battin, and K. Besemer. 2013. Microbial biodiversity in glacier-fed streams. ISME Journal 7:16511660. 